\title{
Contribution of $\mathrm{GABA}_{A}$ and $\mathrm{GABA}_{B}$ Receptors to Thalamic Neuronal Activity during Spontaneous Absence Seizures in Rats
}

\author{
Rainer Staak and Hans-Christian Pape \\ Institute of Physiology, Medical School, Otto-von-Guericke University, 39120 Magdeburg, Germany
}

The contribution of GABAergic mechanisms in thalamic relay nuclei to spike and wave discharges (SWDs) during spontaneous seizures was assessed using the WAG/Rij strain of rats, an established genetic model of absence epilepsy, in combination with single-unit recordings and microiontophoretic techniques in the ventrobasal thalamic complex in vivo. Spontaneous SWDs occurring on the electroencephalogram at 5-9 Hz were associated with burst firing in thalamocortical neurons, which was phase-locked with the spike component. Microiontophoretic application of the $\mathrm{GABA}_{\mathrm{A}}$ receptor antagonist bicuculline significantly increased the magnitude of SWD-related firing in all tested cells. Application of the $\mathrm{GABA}_{\mathrm{B}}$ receptor antagonist CGP 55845A exerted a statistically insignificant modulatory effect on neuronal activity during spontaneous SWDs but significantly attenuated the bicuculline-evoked aggravation of
SWD-related firing. The data indicate that, in thalamocortical neurons, (1) $\mathrm{GABA}_{\mathrm{A}}$ receptor-mediated events are recruited with each SWD, (2) SWD-related activity can be evoked with no significant contribution of $\mathrm{GABA}_{\mathrm{B}}$ receptors, and (3) blockade of $\mathrm{GABA}_{\mathrm{A}}$ receptors potentiates SWD-related activity, presumably through an indirect effect mediated through $\mathrm{GABA}_{\mathrm{B}}$ receptors. These results vote against a predominant or even exclusive contribution of $\mathrm{GABA}_{\mathrm{B}}$ receptors to spontaneous SWDs in thalamic relay nuclei in the WAG/Rij strain, but rather point to a critical role of $\mathrm{GABA}_{\mathrm{A}}$ receptor activation. This conclusion is in support of the view that the two subtypes of GABA receptors play a differential role in fast $(5-10 \mathrm{~Hz})$ and slow $(3 \mathrm{~Hz})$ spikewave paroxysms observed during absence seizures.

Key words: absence epilepsy; spike and wave discharges; thalamus; $G A B A_{A} ; G_{B B A_{B}}$; microiontophoresis; GAERS; WAG/Rij
The electrophysiological hallmark of absence seizures are bilaterally synchronous spike and wave discharges (SWDs) on the electroencephalogram (EEG), typically occurring at three cycles per second (Gloor and Fariello, 1988). Previous results from humans as well as from experimental models have demonstrated that cortical and thalamic networks, which generate and maintain certain sleep rhythms, are also critically involved in the production of SWDs (Snead, 1995). Rhythmogenesis during sleep involves mutually interconnected thalamocortical neurons and GABAergic neurons of the reticular thalamic nucleus (NRT) (Steriade et al., 1993). These mechanisms in the thalamus, and the GABAergic interactions in particular, seem to be crucially involved also in the pathophysiology of absence epilepsy. The function of GABAergic systems is generally preserved in absence epilepsy, and an increase in GABAergic inhibition has been found to potentiate clinical and experimental seizure activity (Snead, 1995). Two established genetic models of absence epilepsy are the Genetic Absence Epilepsy Rats from Strasbourg (GAERS) (Danober et al., 1998) and the WAG/Rij strain of rats (van Luijtelaar and Coenen, 1997). In GAERS and WAG/Rij, SWD duration was exacerbated upon injection of the $\mathrm{GABA}_{\mathrm{A}}$ receptor agonist muscimol (Peeters et al., 1989; Liu et al., 1991). SWDs were similarly potentiated through $\mathrm{GABA}_{\mathrm{A}}$ agonists in a number of models, although not blocked in all models by $\mathrm{GABA}_{\mathrm{A}}$

\footnotetext{
Received July 26, 2000; revised Nov. 14, 2000; accepted Nov. 27, 2000.

This research was supported by Kultusministerium des Landes Sachsen-Anhalt Grant FKZ 1906A/2587B. We thank Sieglinde Staak for expert technical assistance and Anja Reupsch for help with histological procedures.

Correspondence should be addressed to Hans-Christian Pape, Institute of Physiology, Medical School, Otto-von-Guericke University, Leipziger Strasse 44, D-39120 Magdeburg, Germany. E-mail: hans-christian.pape@medizin.unimagdeburg.de.

Copyright (C) 2001 Society for Neuroscience $\quad 0270-6474 / 01 / 211378-07 \$ 15.00 / 0$
}

antagonists such as bicuculline (Snead, 1995). Moreover, injection of agonists and antagonists to the $\mathrm{GABA}_{\mathrm{B}}$ receptor subtype potentiated and dampened SWDs, respectively (Hosford et al., 1992; Liu et al., 1992; Snead, 1992; Vergnes et al., 1997). These findings have led to the hypothesis that an increase in $\mathrm{GABA}_{\mathrm{B}}$ receptor influence, particularly in thalamocortical neurons, contributes to the pathophysiological events associated with SWD generation (Crunelli and Leresche, 1991; Snead, 1992). Studies in slice preparations of the ferret visual thalamus in vitro have indeed demonstrated that an increase in $\mathrm{GABA}_{\mathrm{B}}$ can shift spindle-like activity patterns of thalamocortical neurons toward slower rhythms resembling $3 \mathrm{~Hz}$ SWDs (Bal et al., 1995; Kim et al., 1997; Bal et al., 2000; Blumenfeld and McCormick, 2000). Results from in vivo studies in GAERS, however, have challenged this view: no evidence was found that binding properties, density, or affinity of $\mathrm{GABA}_{\mathrm{B}}$ receptors in the thalamus are altered compared with nonepileptic control rats (Knight and Bowery, 1992; Mathivet et al., 1994) or that rhythmic inhibitory potentials suggestive of $\mathrm{GABA}_{\mathrm{B}}$ responses are generated in thalamocortical neurons during SWDs (Pinault et al., 1998; Charpier et al., 1999).

Therefore, the present study was undertaken to investigate the recruitment of $\mathrm{GABA}_{\mathrm{A}}$ and $\mathrm{GABA}_{\mathrm{B}}$ receptors during spontaneously occurring SWDs, making use of the established WAG/Rij model of absence epilepsy combined with electrophysiological and microiontophoretic in vivo techniques.

\section{MATERIALS AND METHODS}

Acute experiments were performed in 19 male $\mathrm{WAG} / \mathrm{Rij}$ rats, aged between 180 and $300 \mathrm{~d}(210-420 \mathrm{gm})$. All experimental procedures were approved by the Animal Care and Use Committee (53a-42502/2-028/5). Operative procedures were performed under pentobarbital anesthesia (40-50 mg/kg, i.p.). Wounds and pressure edges were infiltrated with xylocaine cream $(2 \%)$. The rat was positioned into a stereotaxic instru- 
ment with bregma and lambda in a horizontal plane. Body temperature was kept constant at $36-38^{\circ} \mathrm{C}$. Epidural EEG was bilaterally monitored [anteroposterior (AP), $+2.0 \mathrm{~mm}$; lateral (L), 3.6-3.8 mm; from bregma].

Recordings were performed under neurolept anesthesia (0.102 \pm 0.006 $\mathrm{mg} \cdot \mathrm{kg}^{-1} \cdot \mathrm{hr}^{-1}$ fentanyl; CuraMed, Karlsruhe, Germany; $6.120 \pm 0.307$ $\mathrm{mg} \cdot \mathrm{kg}^{-1} \cdot \mathrm{hr}^{-1}$ dehydrobenzperidol; Janssen-Cilag, Neuss, Germany). The level of anesthesia was assessed by monitoring of the EEG and by limb withdrawal in response to tactile stimuli. Five-barrel glass electrodes (140 5316; Hilgenberg, Malsfeld, Germany) were used for simultaneous single-unit recording and microiontophoresis. The recording barrel was filled with $0.5 \mathrm{~m}$ sodium acetate. One barrel was filled with $0.5 \mathrm{M}$ sodium acetate containing 2-6\% Chicago sky blue and was used for current balancing and labeling of the recording site. The remaining barrels were filled with CGP 55845A (6 mM in $165 \mathrm{~mm} \mathrm{NaCl}, \mathrm{pH} 3.5$, in general two barrels), bicuculline methiodide (5 $\mathrm{mm}$ in $165 \mathrm{~mm} \mathrm{NaCl}, \mathrm{pH} 3.0)$, and, in some experiments, either GABA ( $0.5 \mathrm{M}, \mathrm{pH} 3.0)$ or baclofen $(15 \mathrm{~mm}, \mathrm{pH}$ 3.5). The impedance (measured at $1 \mathrm{kHz}$ ) of the electrodes was $10-20$ $\mathrm{M} \Omega$. Retaining, ejection, and balance currents were controlled through a NeuroPhore BH-2 (Medical Systems Corporation, Greenvale, NY). Ejection and retention currents were +5 to $+50 \mathrm{nA}$, and -10 to $-20 \mathrm{nA}$, respectively. Drugs were obtained from Sigma (St. Louis, MO), except for CGP 55845A, which was kindly provided by Novartis (Basel, Switzerland). Electrodes were positioned at AP $-3.3 \mathrm{~mm}$, L $3.0 \mathrm{~mm}$ (with reference to bregma) and lowered into the ventrobasal thalamic complex (VB) (depth, 5.3-6.3 mm) using a micropositioner (model 650; David Kopf Instruments, Tujunga, CA). Single-unit activity of VB neurons was recorded with an EXT-20F amplifier (NPI, Tamm, Germany). Recordings were high- and low-pass filtered at 0.5 and $10 \mathrm{kHz}$, respectively. Selectivity and effectiveness of the microiontophoretically applied substances were controlled in the following manner. For $\mathrm{GABA}_{\mathrm{A}}$ receptors, the $\mathrm{GABA}_{\mathrm{A}}$ receptor antagonist bicuculline and GABA were separately applied, and their effects on SWD-related unit activity were tested (Fig. $1 A)$. Next, bicuculline was applied, followed by application of GABA during maintained bicuculline ejection, termination of GABA, and, finally, termination of bicuculline application (Fig. $1 B$ ). Similarly, for $\mathrm{GABA}_{\mathrm{B}}$ receptors, the $\mathrm{GABA}_{\mathrm{B}}$ receptor agonist baclofen was microiontophoretically applied and its effects on SWDs were monitored, followed by application of the $\mathrm{GABA}_{\mathrm{B}}$ receptor antagonist CGP 55845A during maintained baclofen ejection, termination of CGP 55845A, and termination of baclofen (Fig. 1C). In all cells tested that way $(n=24)$, the effects of GABA receptor agonists were reliably and reversibly antagonized during simultaneous application of the specific receptor antagonist. Examples are illustrated in Figure 1. It is important to note that application of GABA readily and completely suppressed unit activity in the thalamus, even at low ejection strengths.

Analog data were fed into a personal computer via an analog-to-digital interface (1401plus; Cambridge Electronics Design, Cambridge, UK). In parallel, all recordings were stored on analog tape for off-line analysis. Data were analyzed using the SPIKE 2 software (Cambridge Electronics Design). Single-unit activity was discriminated from noise using a level-time function of SPIKE 2. Using the maximum peak of the spike component of a given SWD on the EEG as a trigger, peri-event time (PT) histograms were constructed to determine SWD-related neuronal activity (EEG spiketriggered analysis). The counts were calculated in $3 \mathrm{msec}$ bins in a time range $80 \mathrm{msec}$ before and after the spike peak on the EEG. The average number of discharges per each SWD were calculated from the number of spikes in PT histograms divided by the respective number of SWDs. For evaluation of drug effects, SWDs were monitored within intervals of $30 \mathrm{sec}$ duration. When no average change in SWD frequency was observed in at least two subsequent intervals (control period), drug application commenced, and the effect on SWD-related activity was monitored in five subsequent intervals (overall duration of $210 \mathrm{sec}$ ). EEG-triggered PT histograms were calculated from these intervals, each containing the same number of SWD-correlated trials. Thereafter, drug application was interrupted (recovery period), or an additional drug was simultaneously applied and its effects were monitored in intervals as before. Data from different cells were averaged using this protocol for each cell. Numerical values are expressed as mean \pm SEM. Statistical analysis was performed through a two-tailed paired Student's $t$ test (including $F$ test) and the Wilcoxon test, and by linear regression analysis. $t$ test and Wilcoxon test yielded the same results with respect to significant differences between data. $p$ values in text and figures refer to the $t$ test. Differences of $p \leq 0.05$ were considered statistically significant. Animals were killed by an overdose of pentobarbital ( $150 \mathrm{mg} / \mathrm{kg}$, i.p.), and the brain was fixed in $4 \%$ phosphate-buffered paraformaldehyde, $\mathrm{pH}$ 7.4. Chicago sky blue injections were identified in frozen
A
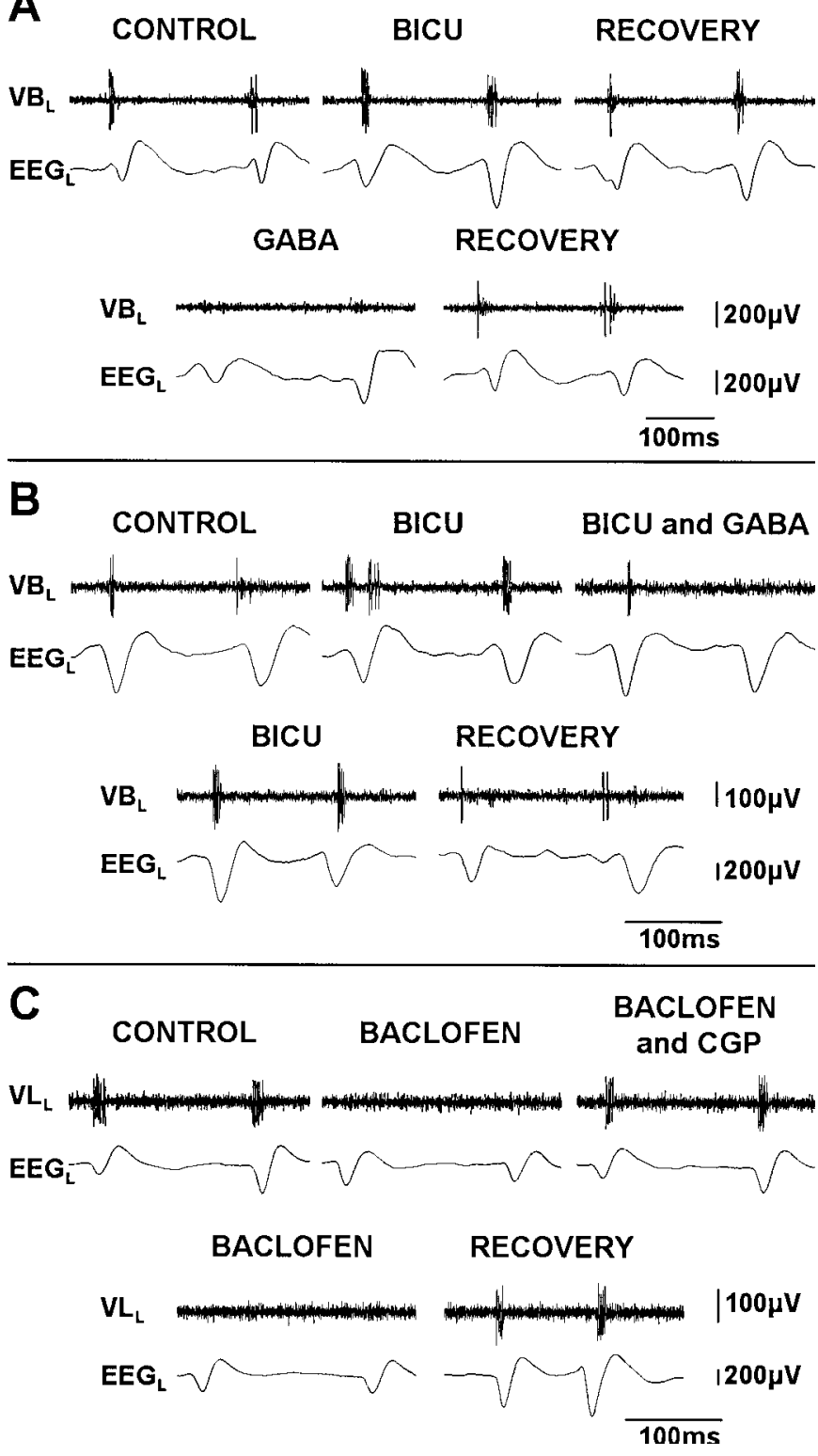

Figure 1. Effectiveness of microiontophoretically applied GABA antagonists on SWD-related thalamic unit activity. $A$, Effects of the $\mathrm{GABA}_{\mathrm{A}}$ receptor antagonist bicuculline $(B I C U)$ and GABA on burst firing of a VB neuron (top trace) related to SWDs on the EEG (bottom trace). Note the increase in SWD-related unit activity by bicuculline and the complete blockade of unit activity by GABA. $B$, Aggravating effect of bicuculline on SWD-related burst firing of a VB neuron is abolished by simultaneous application of GABA. Effects of bicuculline and GABA on seizurerelated burst firing are reversible. $C$, Depressing effect of the $\mathrm{GABA}_{\mathrm{B}}$ receptor agonist baclofen on SWD-related burst firing is antagonized by the $\mathrm{GABA}_{\mathrm{B}}$ receptor antagonist CGP 55845A. Effects created by baclofen and CGP 55845A on seizure-related activity are reversible.

frontal sections of $40 \mu \mathrm{m}$, counterstained with cresyl violet. Only cells from recordings proven to be situated in the VB were included in the analysis.

\section{RESULTS}

\section{Effects of bicuculline on SWD-related firing}

All rats of the WAG/Rij strain investigated under neurolept anesthesia in the present study spontaneously developed bilaterally synchronized SWDs at 5-9 $\mathrm{Hz}$ on the epidural EEG, which started and ended abruptly on a normal background pattern, as 

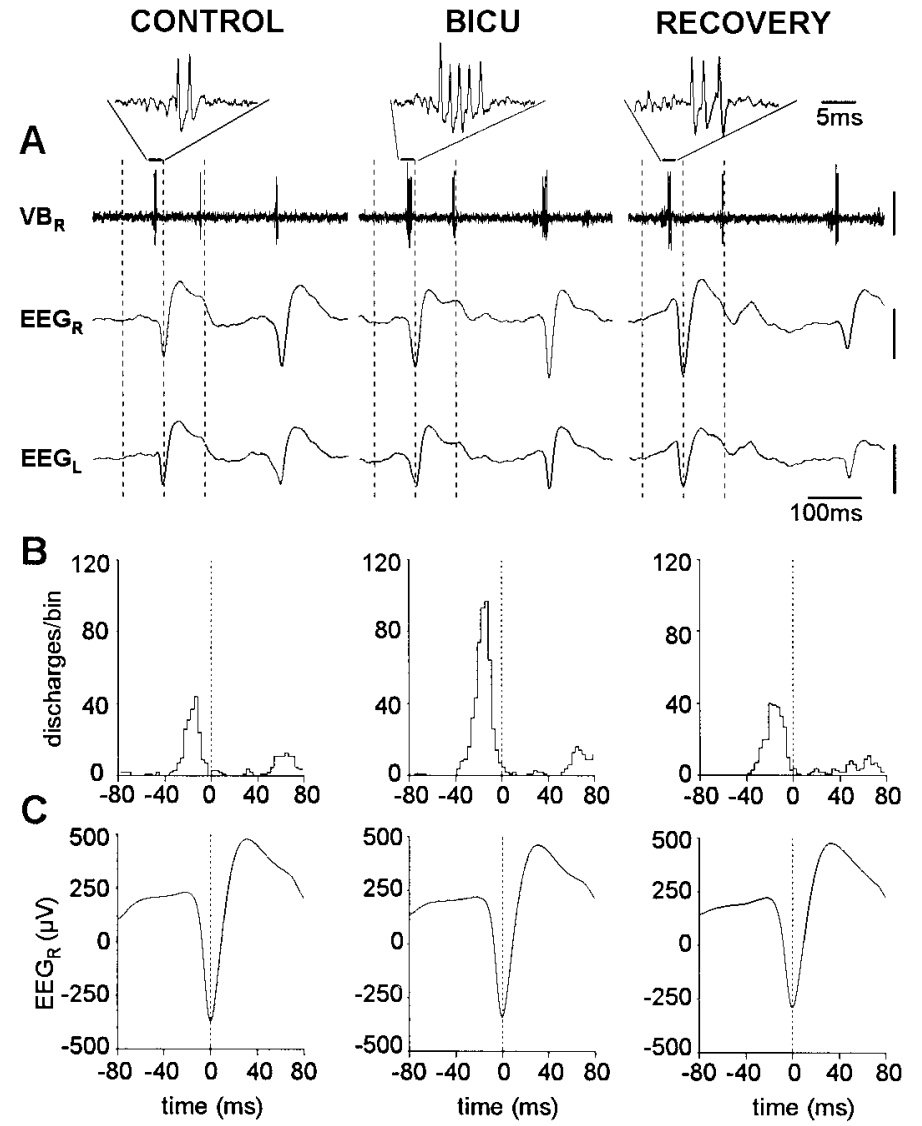

Figure 2. Increase in SWD-related burst firing in the VB upon microiontophoretic application of bicuculline. $A$, Single-unit activity in the right VB (top trace; calibration is $200 \mu \mathrm{V}$ ), phase-locked with the spike component of bilaterally synchronous SWDs on the EEG (middle and bottom traces; calibration is $500 \mu \mathrm{V})$, before $(C O N T R O L)$, during, and after (RECOVERY) application of bicuculline $(B I C U)$. Examples of singleunit burst firing are shown at an enlarged time scale as indicated. Note the occurrence of an afterdischarge after the initial spike-correlated burst. $B$, PT histograms ( $3 \mathrm{msec}$ bins) of activity from the neuron in $A$, triggered by the spike component on the EEG (as shown by dashed lines in $A$ and $C)$, averaged from 126 trials $(C)$.

has been shown previously for this and the GAERS strains (Inoue et al., 1993, 1994; Seidenbecher et al., 1998). Single-unit activity in the VB during these states was characterized by highfrequency burst-like discharges, with each burst consisting of two to several action potentials (Fig. $2 A$ ). PT histograms calculated from EEG spike-triggered analysis revealed the phase-locking of unit activity in the VB with the spike component on the EEG (Fig. 2B) (Inoue et al., 1993; Seidenbecher et al., 1998). The spike-correlated initial burst discharge was followed by a second discharge of one to several action potentials, temporally correlating with the wave component on the EEG, in $11.3 \pm 4.2 \%$ of SWDs $(n=2291)$ (Fig. 2). No silent relay cells were observed during SWDs; in only one relay cell, relatively rare burst discharges occurred, which, however, were temporally correlated with the spike component on the EEG (data not shown).

Microiontophoretic application of the $\mathrm{GABA}_{\mathrm{A}}$ receptor antagonist bicuculline evoked a significant increase in SWD-related activity in all VB neurons tested $(n=23)$. An example is illustrated in Figure 2. Typically, both the spike-correlated initial burst discharge and the delayed afterdischarge were potentiated. The time course of bicuculline effects and the influence on the temporal pattern of SWD-related discharges were investigated more quantitatively in a sample of $12 \mathrm{VB}$ neurons. During local application of bicuculline (see Materials and Methods), the number of action potentials fired by a single VB neuron during one SWD on the EEG steadily and significantly increased from an average of $1.9 \pm 0.5$ spikes to an average of $4.0 \pm 0.6$ spikes within $\sim 3 \mathrm{~min}(p \leq 0.0005)$. Partial recovery was obtained within $50 \mathrm{sec}$ after cessation of drug application (Fig. 3A). PT histograms revealed that bicuculline increased the maximum and duration of the SWD-related firing, but not the latency of onset with respect to occurrence of the spike component on the EEG (Fig. 3B). In addition, the occurrence of a secondary discharge after the initial burst discharge during an SWD was not significantly different before and during action of bicuculline (11.3 \pm 4.2 vs $12.7 \pm 3.7 \%$; $n=2291 ; p=0.47)$. During prolonged ejection of bicuculline, single-unit discharges per SWD maintained at this increased level, with no indication of a fading of bicuculline action for as long as 12 min (longest period of time tested; $n=2-6$ ) (Fig. 3C).

\section{Effects of CGP 55845A}

The effect of the GABA $_{B}$ antagonist CGP 55845A on SWDcorrelated single-unit activity was investigated in $16 \mathrm{VB}$ neurons. Microiontophoretic application of CGP 55845A exerted a continuum of effects, ranging from a decrease by $35 \%$ to an increase to $133 \%$ of SWD-correlated activity in different cells. Two examples are illustrated in Figure $4, A$ and $B$. Linear regression analyses revealed that the maximum effect created by CGP 55845A was not dependent on (1) the number of SWD complexes generated during a $30 \mathrm{sec}$ control period before application, (2) the change in SWD frequency occurring within two subsequent intervals of $30 \mathrm{sec}$ duration before application, (3) the overall spike activity or SWD-correlated spike firing of a given thalamic neuron, or (4) the size of the ejection current (data not shown). Analyzing the effects of CGP 55845A over the whole application period in the population of cells that was investigated revealed that the number of action potentials associated with one SWD on the EEG was not significantly altered (Fig. $4 C$ ).

\section{Blockade of $\mathrm{GABA}_{A}$ and $\mathrm{GABA}_{B}$ receptors}

In nine $\mathrm{VB}$ neurons, the maximum effects created by CGP 55845A were investigated during maintained action of bicuculline. An example is shown in Figure 5, $A$ and $B$. In these neurons, bicuculline induced a maximal increase in seizurerelated neuronal activity from an average of $4.1 \pm 0.9$ to $7.9 \pm$ 1.3 discharges per SWD ( $p \leq 0.002)$. It is important to add that the addition of CGP 55845A was started within $499.9 \pm$ $72.5 \mathrm{sec}$ after the commencement of the ejection of bicuculline, i.e., during constant action of bicuculline (Fig. 3C). The addition of CGP 55845A resulted in a reduction in seizure-related burst firing in all nine tested cells (Fig. 5A,B). The SWDrelated number of discharges significantly $(p<0.001)$ decreased from an average of $7.9 \pm 1.3$ to $6.3 \pm 1.3$ during CGP 55845A application within $218.9 \pm 43.6 \mathrm{sec}$ in the tested population of cells (Fig. $5 C$ ). Linear regression analysis revealed that the maximal effects by CGP 55845A were not dependent on the absolute increase in SWD-related firing caused by bicuculline or the duration of CGP 55845A application until the maximum effect occurred (data not shown). These effects of CGP 55845A were not or only partially reversible after cessation of CGP 55845A application within the tested period of time. 
A

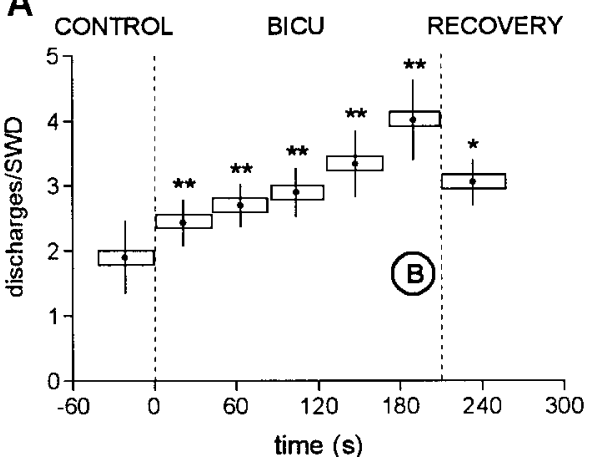

B

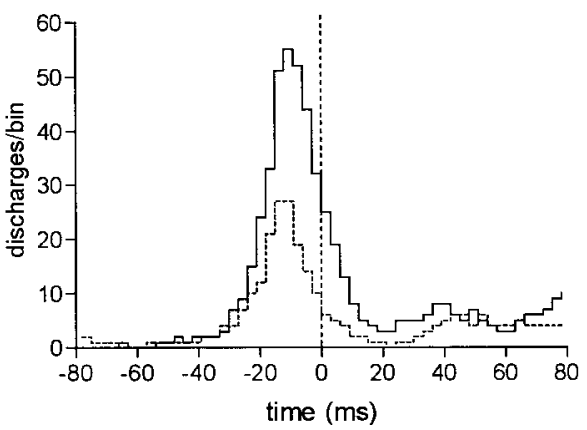

C

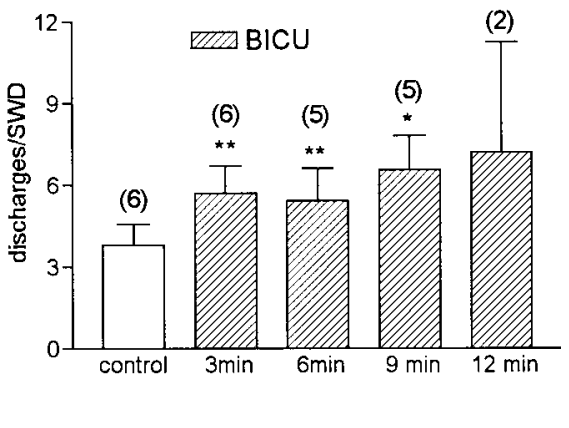

Figure 3. Time course of bicuculline effect and influence on SWD-related single-unit activity. A, Average number of single-unit discharges in the VB associated with one SWD on the EEG, within intervals before (CONTROL), during, and after (RECOVERY) microiontophoretic application of bicuculline $(B I C U)$. Data were obtained from EEG-triggered PT histograms, averaged from recordings in 7-12 neurons. See Materials and Methods for details. An example at the time period indicated is shown in B. Dashed line is control, and solid line is bicuculline. Bin width is 3 msec, $141.9 \pm 5.2$ trials averaged per neuron. Asterisks in $A$ indicate significant differences from control ( $\left.{ }^{*} p<0.05 ; * * p<0.02\right)$. $C$, Lack of fading of bicuculline action during prolonged ejection. Number of single-unit discharges per one SWD, under control conditions and action of bicuculline, averaged within 3 min periods over a total time period of $12 \mathrm{~min}$. Data were obtained from EEG-triggered PT histograms, averaged from recordings in two to six neurons (139.5 \pm 12.3 trials averaged per neuron). Number of neurons are given in parenthesis. Asterisks indicate significant differences $\left({ }^{*} p<0.05 ; * * p<0.02\right)$.

\section{DISCUSSION}

Compared with experimental models of absence epilepsy that use pharmacologically active substances to produce epileptiform activity, the present results were obtained in the WAG/Rij strain in vivo, which bears the advantage of studying spontaneously occurring SWDs in the thalamocortical synaptic network. Furthermore, neuroactive substances were microiontophoretically applied during single-unit recording, thereby allowing to study the contribution of local synaptic mechanisms to SWD-correlated activity in single thalamic neurons without altering the principle characteristics of the seizures or seizure generation. The experiments were performed under light neurolept anesthesia, which reportedly facilitates the generation of SWDs without altering the characteristics of paroxysmal discharges or associated behavioral traits (Inoue et al., 1994). The present results indicate that, in thalamocortical neurons during absence seizures, (1) $\mathrm{GABA}_{\mathrm{A}^{-}}$ mediated events are recruited with each SWD, (2) SWD-related activity can be evoked with no significant contribution of $\mathrm{GABA}_{\mathrm{B}}$ receptors, and (3) blockade of $\mathrm{GABA}_{\mathrm{A}}$ receptors potentiates SWD-related activity, presumably through an indirect effect mediated through $\mathrm{GABA}_{\mathrm{B}}$ receptors.

These results confirm the involvement of GABAergic mechanisms in the thalamus during SWD generation. The thalamocortical circuits involved in SWD generation are those that normally sustain spindle waves, which appear on the EEG as synchronized waves of electrical activity at $7-14 \mathrm{~Hz}$ during early stages of slow-wave sleep (Steriade et al., 1993, 1994). Important mechanisms of spindling are reciprocal interactions between GABAergic NRT neurons and thalamocortical neurons (McCormick and Bal, 1997). The release of GABA from NRT neurons onto thalamocortical neurons results in a membrane hyperpolarization and associated removal of inactivation from a T-type calcium current, which, in turn, activates upon repolarization and triggers a rebound burst of fast action potentials. The transfer of this burst activity via excitatory synaptic connections to NRT neurons results in correlated bursting and GABA release, and the cycle starts again. Rhythmic burst activity spreads as a propagating wave through recruitment of neurons in the thalamocortical network, resulting in spindle waves on the EEG (Contreras et al., 1996; McCormick and Bal, 1997). The shift from spindle waves to
A

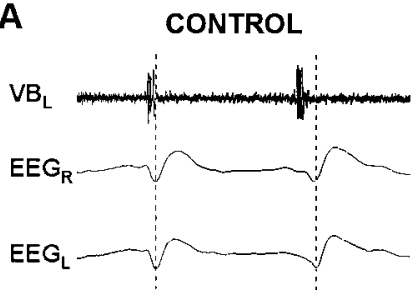

B CONTROL
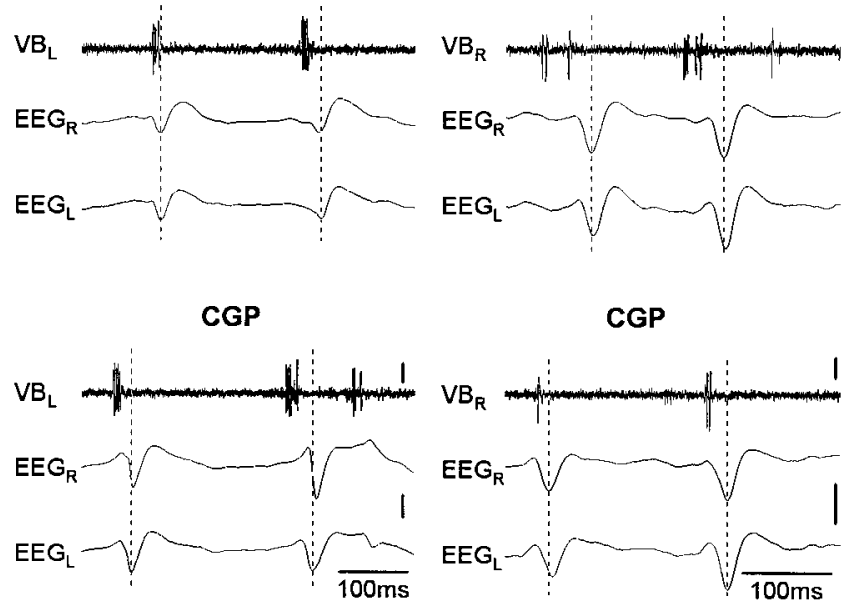

\section{C}

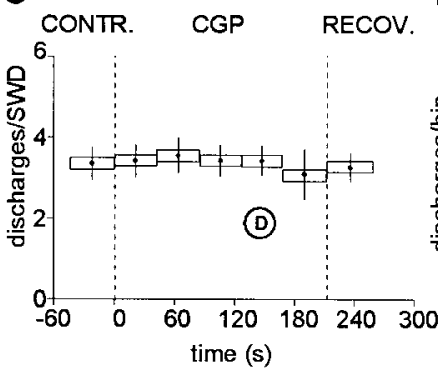

D
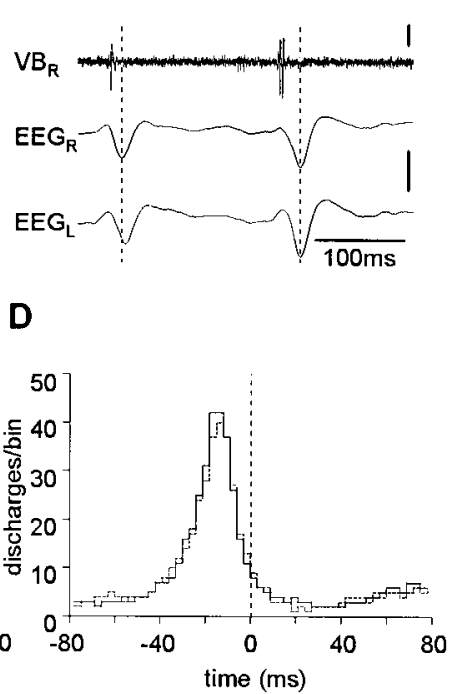

Figure 4. Effects of CGP 55845A on SWD-related burst firing in the VB. Examples in $A$ and $B$ illustrate burst firing in two single VB units (top traces; calibration is $100 \mu \mathrm{V}$ ) phase-locked with the spike component on the EEG (bottom traces; calibration is $500 \mu \mathrm{V}$ ) before (CONTROL) and during application of CGP 55845A. Note the slight facilitatory $(A)$ and disfacilitatory $(B)$ effect of CGP 55845A. $C$, Average number of singleunit discharges associated with one SWD on the EEG, within intervals before (CONTR.), during, and after (RECOV.) application of CGP 55845A. Data were obtained from EEG-triggered PT histograms, averaged from recordings in 9-16 neurons. See Materials and Methods for details. An example at the time period indicated is shown in $D$. Bin width is $3 \mathrm{msec}, 136.5 \pm 11.5$ trials averaged per neuron. 

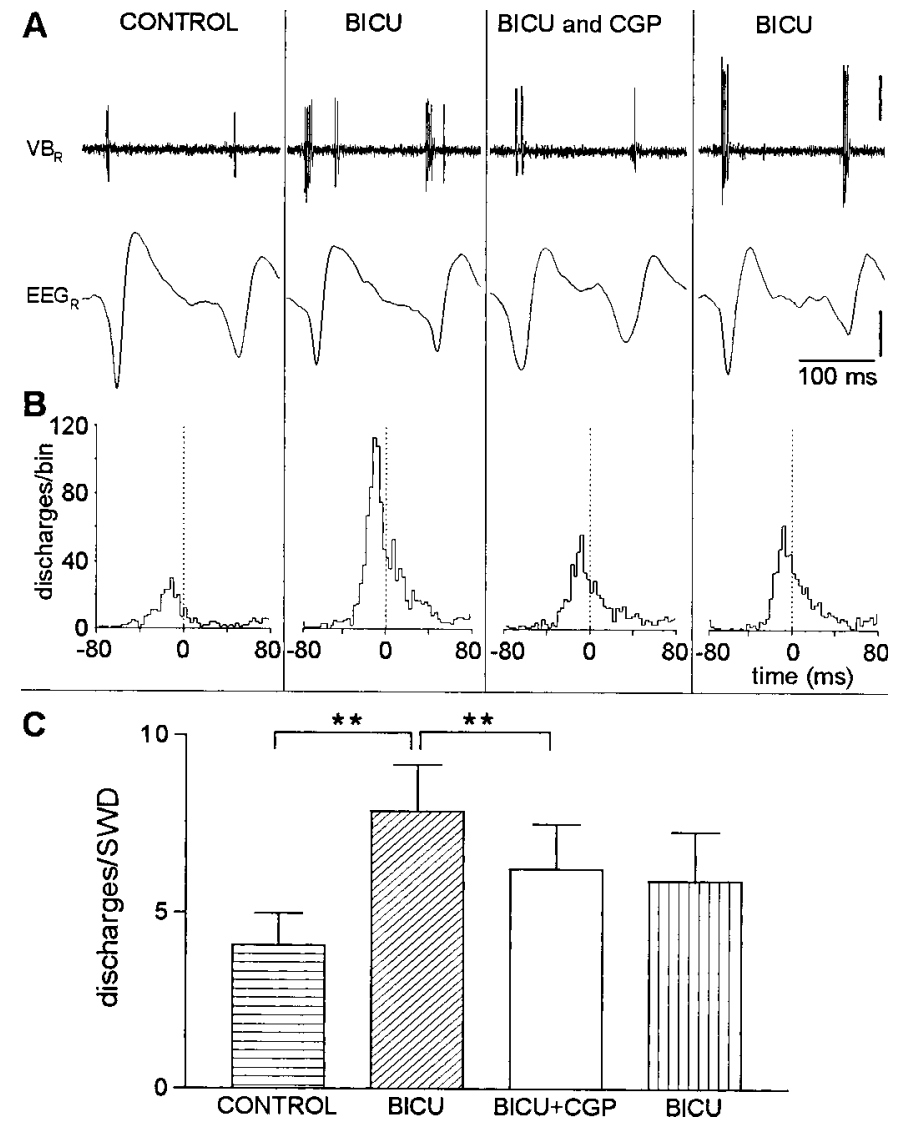

Figure 5. Effects of CGP 55845A during maintained action of bicuculline. A, Examples of single-unit burst firing in the VB (top trace; calibration is $200 \mu \mathrm{V}$ ) phase-locked with the spike component on the EEG (bottom trace; calibration is $250 \mu \mathrm{V}$ ) under control conditions, during application of bicuculline, addition of CGP 55845A during maximal effects of bicuculline, and removal of CGP 55845A. B, PT histograms (3 msec bins) of activity from the neuron in $A$, triggered by the spike component on the EEG, averaged from 234 trials ( $3 \mathrm{msec}$ bins). $C$, Average number of single-unit discharges in the VB associated with one SWD on the EEG, under control conditions, during maximal action of bicuculline $(B I C U)$, bicuculline and CGP 55845A (CGP), and after removal of CGP 55845A. Data were obtained from EEG-triggered PT histograms, averaged from recordings in nine neurons $(151.7 \pm 16.7$ trials averaged per neuron). Asterisks indicate significant differences ${ }^{* *} p<$ $0.005)$.

SWDs is associated with an increase in the degree of synchronization in the thalamus and a shift in the predominant frequency from 7-14 to $\sim 3 \mathrm{~Hz}$ (Steriade et al., 1994). Although this scenario seems to be generally accepted, an as yet unresolved question relates to the involvement of $\mathrm{GABA}_{\mathrm{A}}$ and $\mathrm{GABA}_{\mathrm{B}}$ receptors in thalamocortical neurons. One line of evidence, mostly derived from in vitro models, indicates that $7-14 \mathrm{~Hz}$ spindle-like rhythmic activity in thalamic networks is associated with a predominant activation of $\mathrm{GABA}_{\mathrm{A}}$ receptors in thalamocortical neurons, whereas an increased or exclusive contribution of $\mathrm{GABA}_{\mathrm{B}}$ receptors results in $\sim 3 \mathrm{~Hz}$ oscillations indicative of paroxysmal discharges (Crunelli and Leresche, 1991; McCormick and Bal, 1997). The mechanistic basis being that activation of $\mathrm{GABA}_{\mathrm{B}}$ receptors mediates hyperpolarizing membrane responses (through an increase in potassium conductance), whose amplitude and duration are increased compared with those upon $\mathrm{GABA}_{\mathrm{A}}$ activation (associated with an increase in chloride conductance). This then results in an increased de-inactivation of the T-type calcium current and facilitated production of rebound burst activity at intervals of $\sim 300 \mathrm{msec}$, similar to intervals of paroxysmal oscillations (Crunelli and Leresche, 1991). Studies in slice preparations of the ferret visual thalamus in vitro have indeed demonstrated that enhanced burst firing in cortical or NRT inputs can result in an increase in $\mathrm{GABA}_{\mathrm{B}}$ responses and associated transition from spindle-like to paroxysmal-like oscillations (Kim et al., 1997; Bal et al., 2000; Blumenfeld and McCormick, 2000).

The present findings confirm these conclusions, in that a bicuculline-sensitive, most likely $\mathrm{GABA}_{\mathrm{A}}$ receptor-mediated component of discharges was recruited during each SWD. The present data do not support, however, the hypothesis of a significant or even exclusive contribution of $\mathrm{GABA}_{\mathrm{B}}$ receptors to spontaneous SWDs in thalamocortical neurons in this model, because the $\mathrm{GABA}_{\mathrm{B}}$ receptor antagonist CGP 55845A had no significant effect on SWD-related burst firing. In agreement with this conclusion are recent intracellular studies in GAERS, which obtained evidence for the occurrence of rhythmic inhibitory potentials suggestive of $\mathrm{GABA}_{\mathrm{A}}$ but not $\mathrm{GABA}_{\mathrm{B}}$ receptor activation during SWDs in thalamocortical neurons (Pinault et al., 1998; Charpier et al., 1999). Previous studies involving systemic application or microinjection into the thalamus of $\mathrm{GABA}_{\mathrm{A}}$ or $\mathrm{GABA}_{\mathrm{B}}$ antagonists and/or agonists in GAERS or WAG/Rij (Liu et al., 1991, 1992; Snead, 1992; Vergnes et al., 1997) are difficult to compare with the present one, because the basic activity of large populations of cells may have been affected, regardless of the mechanisms by which single neurons are recruited during each SWD. In fact, the number, affinity, and expression of $\mathrm{GABA}_{\mathrm{A}}$ and $\mathrm{GABA}_{\mathrm{B}}$ receptors are not altered in the thalamus of epileptic compared with control rats (Knight and Bowery, 1992; Snead et al., 1992; Mathivet et al., 1994), arguing against an imbalance in receptor populations. That $\mathrm{GABA}_{\mathrm{B}}$ receptors are operative (and pharmacologically responsive) under the present experimental conditions is demonstrated during pharmacological blockade of $\mathrm{GABA}_{\mathrm{A}}$ receptors, which resulted in a CGP 55845A-sensitive enhancement of SWD-related burst firing. It seems reasonable to speculate that these effects reflect the enhancement of $\mathrm{GABA}_{\mathrm{B}}$-mediated inhibitory potentials upon blockade of $\mathrm{GABA}_{\mathrm{A}}$ receptors, as observed in thalamocortical neurons in vitro (Crunelli and Leresche, 1991) and which has indeed been observed to facilitate paroxysmal-like oscillations in thalamic networks in vitro (Kim et al., 1997). The underlying mechanistic basis is presumably a reduction in shunting effect of the $\mathrm{GABA}_{\mathrm{A}}$ chloride conductance (Crunelli and Leresche, 1991) and/or transsynaptic effects mediated via $\mathrm{GABA}_{\mathrm{B}}$ receptors (Mody et al., 1994) during blockade of $\mathrm{GABA}_{\mathrm{A}}$ receptors.

It is important to note that SWDs in WAG/Rij occur at a range of 5-10 Hz (Inoue et al., 1994), thereby differing from the "classical" $\sim 3 \mathrm{~Hz}$ SWDs seen in the EEG of human petit mal patients (Malafosse et al., 1994) and various experimental models, including monkeys (Steriade, 1974) and cats (Gloor and Fariello, 1988). These differences may indicate the involvement of multiple mechanisms in the generation of different forms of SWDs. For instance, a computational model suggested that the two different frequency ranges, 2-4 and 5-10 $\mathrm{Hz}$, reflect the predominant influence of $\mathrm{GABA}_{\mathrm{A}}$ and $\mathrm{GABA}_{\mathrm{B}}$ receptors in thalamocortical relay cells, respectively (Destexhe, 1999). The present study provides experimental evidence in support of this model in that $\mathrm{GABA}_{\mathrm{A}}$ receptors were found to be activated upon 5-9 $\mathrm{Hz}$ spike-wave oscillations in thalamocortical neurons during spontaneous seizures, whereas $\mathrm{GABA}_{\mathrm{B}}$ receptors did not significantly contribute. In line with these results are the findings by Castro- 
Alamancos (1999) that infusion of $\mathrm{GABA}_{\mathrm{A}}$ receptor antagonists into the thalamus induced two forms of epileptiform discharges in neocortex, namely $3 \mathrm{~Hz}$ discharges blocked by thalamic inf usion of $\mathrm{GABA}_{\mathrm{B}}$ antagonists and $12 \mathrm{~Hz}$ discharges insensitive to thalamic infusion of $\mathrm{GABA}_{\mathrm{B}}$ antagonists. Following from that and the present study is the conclusion that activation of $\mathrm{GABA}_{\mathrm{A}}$ receptors in thalamocortical neurons plays a critical role during generation of the "fast" 5-10 Hz spike-wave paroxysms and that blockade of the $\mathrm{GABA}_{\mathrm{A}}$ receptors can unmask a $\mathrm{GABA}_{\mathrm{B}}$ receptor-mediated component during SWDs. That a shift in the major frequency of burst discharges from $5-10$ to $\sim 3 \mathrm{~Hz}$, as typically occurs upon blockade of $\mathrm{GABA}_{\mathrm{A}}$ receptors in vitro or widespread infusion of $\mathrm{GABA}_{\mathrm{A}}$ antagonists in vivo, has not been observed in the present study is most likely attributable to the very localized application of the receptor antagonist through microiontophoresis, which cannot be expected to change the general characteristics of a spontaneous SWD. In any case, the conclusion of a significant contribution of $\mathrm{GABA}_{\mathrm{A}}$ receptor activation in thalamic relay neurons to the production of spike-wave paroxysms may relate to the clinical observation that phenobarbital can worsen absence seizures (Malafosse et al., 1994). Similar conclusions have been reached in the lethargic mouse model, in which the production of 5-6 Hz epileptiform spike bursts on the EEG was facilitated upon microinjection of low concentrations of muscimol or phenobarbital into thalamic relay nuclei (Hosford et al., 1997). Absence seizures in that model have been reported to be also regulated by $\mathrm{GABA}_{\mathrm{B}}$ receptors in the thalamus, although by a receptor subpopulation restricted to particular thalamic structures not involving prototypical relay nuclei (Hosford et al., 1995). In fact, $\mathrm{GABA}_{\mathrm{B}}$ responses were unaltered in VB neurons of lethargic compared with control mice (Caddick and Hosford, 1996). That $\mathrm{GABA}_{\mathrm{B}}$ receptors may play a role for modulating SWD patterns also in thalamic relay nuclei of the rat models under study cannot be ruled out. For instance, the presence of a long-lasting hyperpolarizing response enveloping SWD-related paroxysmal oscillations in thalamocortical neurons in GAERS has been suggested to represent functional $\mathrm{GABA}_{\mathrm{B}}$ receptors (Pinault et al., 1998), which may contribute to the rather variable (albeit statistically not significant) effect of CGP 55845A observed in the present study.

In summary, experimental as well as computational models of absence epilepsies suggest that GABA receptors in thalamic relay nuclei are differentially recruited during the production of thalamocortical oscillations related to seizures, with $\mathrm{GABA}_{\mathrm{A}}$ receptors predominating during fast $(5-10 \mathrm{~Hz})$ and $\mathrm{GABA}_{\mathrm{B}}$ receptors predominating during slow $(2-4 \mathrm{~Hz})$ spike-wave paroxysms, respectively. However, available evidence seems to be difficult to reconcile with the hypothesis that an imbalance of GABAergic neurotransmission within thalamic relay nuclei per se is critically involved in SWD generation during spontaneous seizures in genetic rat models (Danober et al., 1998). The increase in extracellular GABA concentration in thalamic relay nuclei in epileptic compared with control rats (Richards et al., 1995) with no associated change in the number of GABAergic neurons (Spreafico et al., 1993) may not necessarily relate to an alteration of GABAergic mechanisms within these nuclei but rather to a potentiated burst firing of GABAergic NRT neurons resulting from an increased expression of T-type calcium channels (Tsakiridou et al., 1995; Talley et al., 2000) and/or an indirect effect mediated via recurrent inputs from a hyperexcitable cortex (Bal et al., 2000; Blumenfeld and McCormick, 2000).

\section{REFERENCES}

Bal T, von Krosigk M, McCormick DA (1995) Synaptic and membrane mechanisms underlying synchronized oscillations in the ferret lateral geniculate nucleus in vitro. J Physiol (London) 483:641-663.

Bal T, Debay D, Destexhe A (2000) Cortical feedback controls the frequency and synchrony of oscillations in the visual thalamus. J Neurosci 20:7478-7488.

Blumenfeld H, McCormick DA (2000) Corticothalamic inputs control the pattern of activity generated in thalamocortical networks. J Neurosci 20:5153-5162.

Caddick SJ, Hosford DA (1996) The role of GABA $_{\mathrm{B}}$ mechanisms in animal models of absence seizures. Mol Neurobiol 13:23-32.

Castro-Alamancos MA (1999) Neocortical synchronized oscillations induced by thalamic disinhibition in vivo. J Neurosci 19:RC27.

Charpier S, Leresche N, Deniau J-M, Mahon S, Hughes SW, Crunelli V (1999) On the putative contribution of $\mathrm{GABA}_{\mathrm{B}}$ receptors to the electrical events occurring during spontaneous spike and wave discharges. Neuropharmacology 38:1699-1706.

Contreras D, Destexhe A, Sejnowski TJ, Steriade M (1996) Control of spatiotemporal coherence of a thalamic oscillation by corticothalamic feedback. Science 274:771-774.

Crunelli V, Leresche N (1991) A role for $\mathrm{GABA}_{\mathrm{A}}$ receptors in excitation and inhibition of thalamocortical cells. Trends Neurosci 14:16-21.

Danober L, Deransart C, Depaulis A, Vergnes M, Marescaux C (1998) Pathophysiological mechanisms of genetic absence epilepsy in the rat. Prog Neurobiol 55:27-57.

Destexhe A (1999) Can GABA $_{\mathrm{A}}$ conductances explain the fast oscillation frequency of absence seizures in rodents? Eur $\mathrm{J}$ Neurosci 11:2175-2181.

Gloor P, Fariello RG (1988) Generalized epilepsy: some of its cellular mechanisms differ from those of focal epilepsy. Trends Neurosci 11:63-68.

Hosford DA, Clark S, Cao Z, Wilson Jr WA, Lin FH, Morrisett RA, Huin A (1992) The role of $\mathrm{GABA}_{\mathrm{B}}$ receptor activation in absence seizures of lethargic (lh/lh) mice. Science 257:398-401.

Hosford DA, Lin F, Kraemer DL, Cao Z, Wang Y, Wilson Jr JT (1995) Neural network of structures in which $\mathrm{GABA}_{\mathrm{B}}$ receptors regulate absence seizures in the lethargic (lh/lh) mouse model. J Neurosci 15:7367-7376.

Hosford DA, Wang Y, Cao Z (1997) Differential effects mediated by $\mathrm{GABA}_{\mathrm{A}}$ receptors in thalamic nuclei in $\mathrm{lh} / \mathrm{lh}$ model of absence seizures. Epilepsy Res 27:55-65.

Inoue M, Duysens J, Vossen JMH, Coenen AML (1993) Thalamic multiple-unit activity underlying spike-wave discharges in anesthetized rats. Brain Res 612:35-40.

Inoue M, Ates N, Vossen JMH, Coenen AML (1994) Effects of the neuroleptanalgesic fentanyl-fluanisone (hypnorm) on spike-wave discharges in epileptic rats. Pharmacol Biochem Behav 48:547-551.

Kim U, Sanchez-Vives MV, McCormick DA (1997) Functional dynamics of GABAergic inhibition in the thalamus. Science 278:130-134.

Knight AR, Bowery NG (1992) GABA receptors in rats with spontaneous generalized nonconvulsive epilepsy. J Neural Transm Suppl 35:189-196.

Liu Z, Vergnes M, Depaulis A, Marescaux C (1991) Evidence for a critical role of GABAergic transmission within the thalamus in the genesis and control of absence seizures in the rat. Brain Res 545:1-7.

Liu Z, Vergnes M, Depaulis A, Marescaux C (1992) Involvement of intrathalamic $\mathrm{GABA}_{\mathrm{B}}$ neurotransmission in the control of absence seizures in the rat. Neuroscience 48:87-93.

Malafosse A, Genton P, Hirsch E, Marescaux C, Broglin D, Bernasconi R (1994) Idiopathic generalized epilepsies: clinical, experimental and genetic aspects. London: Libbey.

Mathivet P, Bernasconi R, de Barry J, Mickel S, Froestl W, Bittiger H (1994) Characteristics of $\mathrm{GABA}_{\mathrm{B}}$ receptor binding sites in genetic absence epilepsy rats from Strasbourg (GAERS) and in non-epileptic rats. In: Idiopathic generalized epilepsies: clinical, experimental and genetic aspects (Malafosse A, Genton P, Hirsch E, Marescaux C, Broglin D, Bernasconi R, eds), pp 177-185. London: Libbey.

McCormick DA, Bal T (1997) Sleep and arousal: thalamocortical mechanisms. Annu Rev Neurosci 20:185-215.

Mody I, DeKoninck Y, Otis TS, Soltesz I (1994) Bridging the cleft at GABA synapses in the brain. Trends Neurosci 17:517-527.

Peeters BWMM, van Rijn CM, Vossen JMH, Coenen AML (1989) Effects of GABA-ergic agents on spontaneous non-convulsive epilepsy, EEG and behaviour, in the WAG/Rij inbred strain of rats. Life Sci 45:1171-1176.

Pinault D, Leresche N, Charpier S, Deniau J-M, Marescaux C, Vergnes M, Crunelli V (1998) Intracellular recordings in thalamic neurones during spontaneous spike and wave discharges in rats with absence epilepsy. J Physiol (Lond) 509:449-456.

Richards DA, Lemons T, Whitton PS, Bowery NG (1995) Extracellular GABA in the ventrolateral thalamus of rats exhibiting spontaneous absence epilepsy: a microdialysis study. J Neurochem 65:1674-1680.

Seidenbecher T, Staak R, Pape H-C (1998) Relations between cortical 
and thalamic cellular activities during absence seizures in rats. Eur J Neurosci 10:1103-1112.

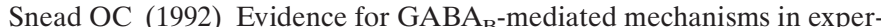
imental generalized absence seizures. Eur J Pharmacol 213:343-349.

Snead OC (1995) Basic mechanisms of generalized absence seizures. Ann Neurol 37:146-157.

Snead OC, Depaulis A, Banerjee PK, Hechler V, Vergnes M (1992) The $\mathrm{GABA}_{\mathrm{A}}$ receptor complex in experimental absence seizures in rat: an autoradiographic study. Neurosci Lett 140:9-12.

Spreafico R, Mennini T, Danober L, Cagnotto A, Regondi MC, Miari A, De Blas A, Vergnes M, Avanzini G (1993) GABA ${ }_{A}$ receptor impairment in the genetic absence epilepsy rats from Strasbourg (GAERS): an immuno-cytochemical and receptor binding autoradiographic study. Epilepsy Res 15:229-238.

Steriade M (1974) Interneuronal epileptic discharges related to spikeand-wave cortical seizures in behaving monkeys. Electroencephalogr Clin Neurophysiol 37:247-263.
Steriade M, McCormick DA, Sejnowski TJ (1993) Thalamocortical oscillations in the sleeping and aroused brain. Science 262:679-685.

Steriade M, Contreras D, Amzica F (1994) Synchronized sleep oscillations and their paroxysmal developments. Trends Neurosci 17:199-208.

Talley EM, Solorzano G, Depaulis A, Perez-Reyes E, Bayliss DA (2000) Low-voltage-activated calcium channel subunit expression in a genetic model of absence epilepsy in the rat. Mol Brain Res 75:159-165.

Tsakiridou E, Bertollini L, de Curtis M, Avanzini G, Pape HC (1995) Selective increase in T-type calcium conductance of reticular thalamic neurons in a rat model of absence epilepsy. J Neurosci 15:3110-3117. van Luijtelaar G, Coenen A (1997) The WAG/Rij rat model of absence epilepsy: ten years of research. Nijmegen, The Netherlands: Nijmegen UP.

Vergnes M, Boehrer A, Simler S, Bernasconi R, Marescaux C (1997) Opposite effects of GABA $_{\mathrm{B}}$ receptor antagonists on absences and convulsive seizures. Eur J Pharmacol 332:245-255. 